Agriculture and Food Sciences Research Vol. 6, No. 2, 166-171, 2019 $\operatorname{ISSN}(E)$ 2411-6653/ISSN(P) 2518-0193 DOI: 10.20448/journal.512.2019.62.166.171 (1) 2019 by the authors; licensee Asian Online Journal Publishing Group

check for
updates

\title{
Nutrient Content Assessment of Six Citrus Species Parts and their Feedstuff Significance
}

\section{Chinelo A. Ezeabara ${ }^{\circledR}$ \\ Okeke C.U. ${ }^{2}$}

"Department of Botany, Nnamdi Azikiwe University, P.M.B. 5025, Awwa, Anambra State, Nigeria.

'Email:ca.ezeabara@unizik.edu.ng.

Email:cuokeke@yahoo.com

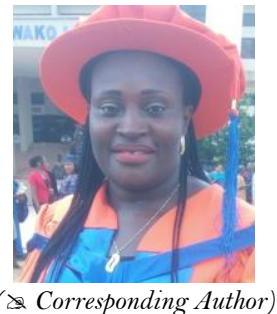

\section{Abstract}

Insufficient and high cost of good quality feed is the primary limitation to livestock operation. Hence, assessment of surplus atypical feed resources for their nutritive potential to support livestock productivity becomes topical. Dry matter bases of the roots, stems, stem barks, leaves and peels of six Citrus species that are commonly available in Southeastern Nigeria were investigated for nutrient composition. High value of crude protein ranging from 15 to 18 percent was found in the leaves of all the species. High carbohydrate values ranged from 70 to 81 percent, in the peels of C. grandis, C. reticulata, C. paradisii and C. sinensis. High percentage of fat was also present in the range of 12 to $13 \%$ in the peels of C. aurantifolia and C. sinensis. Ash contents were very high in the leaves of C. aurantifolia, C. grandis, C. limon and C. paradisii, ranging from 10 to $14 \%$. Therefore, leaves and peels of these Citrus species could be regarded as low cost and locally available alternative high-quality animal feeds.

Keywords: Animal feed, Animal protein, Animal nutrition, Citrus leaves, Citrus peels, Crude protein, feed quality, Nutritive value.

Citation | Chinelo A. Ezeabara; Okeke C.U. (2019). Nutrient Content Assessment of Six Citrus Species Parts and their Feedstuff Significance. Agriculture and Food Sciences Research, 6(2): 166-171. History:

Received: 28 March 2019

Revised: 8 May 2019

Accepted: 10 June 2019

Published: 22 July 2019

Licensed: This work is licensed under a Creative Commons Attribution 3.0 License (c) EY EY

Publisher: Asian Online Journal Publishing Group
Contribution/Acknowledgement: Both authors contributed to the conception and design of the study.

Funding: This study received no specific financial support.

Competing Interests: The authors declare that they have no conflict of interests.

Transparency: The authors confirm that the manuscript is an honest, accurate, and transparent account of the study was reported; that no vital features of the study have been omitted; and that any discrepancies from the study as planned have been explained.

Ethical: This study follows all ethical practices during writing.

\section{Contents}

1. Introduction

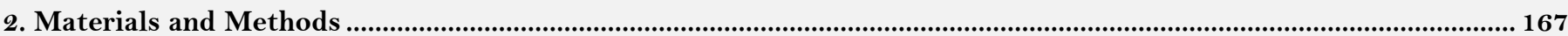

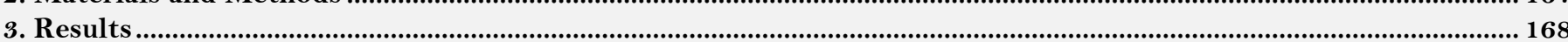

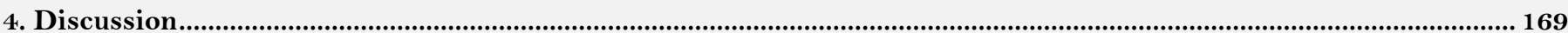

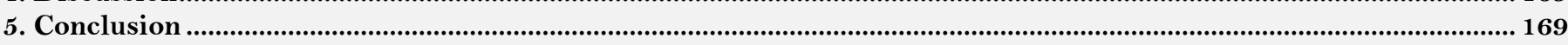

References 


\section{Contribution of this paper to the literature}

This study suggested that Citrus aurantifolia (Christm.) Swingle, C. grandis Osbeck, C. limon (L.) Burm. f., C. paradisii Macf., C. reticulata Blanco and C. sinensis (L.) Osbeck leaves and peels are potential alternative high-quality animal feeds.

\section{Introduction}

Citrus belongs to the family Rutaceae. Six species of Citrus are commonly available in southeastern Nigeria. They include: Citrus aurantifolia (Christm.) Swingle (Lime), C. grandis Osbeck (Shaddock/Pummelo), C. limon (L.) Burm. f. (Lemon), C. paradisii Macf. (Grapefruit), C. reticulata Blanco (Mandarin/Tangerine), and C. sinensis (L.) Osbeck (Sweet orange).The members of this genus are small trees or large shrubs, reaching 5 to 15 meters tall, with spiny shoots and alternately arranged evergreen leaves with an entire margin $[1,2]$. The coriaceous evergreen leaves are gland dotted and unifoliate-compound with a joint between leaf blade and petiole [1,3].

Citrus fruits are one of the world's most crucial, tasty and juicy fruit of Rutaceae [4,5]. They have long been regarded as important sources of vitamin $\mathrm{C}$; medicinal plant [6] and in the manufacture of household products. However, only the juices and the essential oils, which the antimicrobial property [7] and anti-aflatoxigenic activity [8] have been investigated. The use of Citrus pulp as a common animal feed had also been reported [9]. Thus, it becomes absolutely imperative to investigate other Citrus plants parts for nutritional composition with the view to support livestock productivity.

Good nutrition is an integral part of successful livestock operation. Nutrients are chemical substances in food that nourish the body by providing energy, building materials, and factors to regulate needed chemical reactions in the body [10]. The groundwork of livestock production system is the accessibility of quality and quantity of animal feed, with feed costs taking up to $70 \%$ of the cost of production [11]. Moreover, improper animal feeding and nutrition, either unbalanced diet, under or over feeding of livestock affect the general well-being of the animals, including lowering their body immune system. Protein is one of the most expensive nutrients and an extremely important nutrient in all animal feed. Consumption of small protein and food energy could develop protein-energy malnutrition [12]. The deficiency eventually results in body wasting, primarily of lean tissue, and increased susceptibility to infections.

Moreover, the deliberation for herdsmen to rear cattle in ranches in Nigeria is ongoing. Nigeria had over 14.73 million cattle consisting of 1.47 million milking cows and 13.26 million beef cattle in 2008 [13, 14]. The number must have undoubtedly increased by now. Plant materials are the chief diets of livestock. High cost of animal feeds is among the major factors limiting animal production in Nigeria $[15,16]$. There is shortage of good quality feeds needed to sustain livestock growth especially during dry season, as a result of scarcity of forages. Although many livestock farmers formulate their own animal feed, they have challenges of access to low cost, good quality and easily available raw materials. Besides, feeding animals with crops could reduce the available food for humanity, considering the problem of food shortage as a result of human population explosion in developing countries. Hence, other alternative sources such as agro-industrial by-products and crop residues are being assessed for their nutritive quality to support livestock productivity. The objective of this study therefore, is to determine the nutritive value of various Citrus species parts that are predominant in southeastern, Nigeria.

\section{Materials and Methods}

\subsection{Sources of Materials}

The roots, stems, stem barks, leaves and fruits of Citrus aurantifolia, C. grandis, C. limon, C. paradisii, C. reticulata and $C$. sinensis were collected in the months of November - December at optimum maturity, from Agricultural and Natural Resources Department Market Garden, Amawbia, Anambra State, Nigeria. The voucher specimens were deposited at Department of Botany Herbarium, Nnamdi Azikiwe University, Awka, Anambra State, Nigeria.

\subsection{Preparation of Plant Materials}

The rinds of healthy ripe fruits of the six Citrus species were peeled off with a knife. The roots, stems, stem barks and peels were sun dried for seven days whereas the leaves were air dried in the laboratory at room temperature for ten days. The dried samples (about $1.5 \mathrm{~kg}$ ) were then crushed with mortar and pestle before grinding into fine powder using a manual grinder (Corona, USA).

\subsection{Proximate Determination}

The nutrient content of the six Citrus species parts were determined according to the methods described by Onwuka [17].

\subsubsection{Moisture Content Determination}

The dishes were washed thoroughly and dried in the oven. They were latter put inside the dessicator to cool. After which they were weighed. Sample was put into the weighed dish and weight taken. The sample was dried in the oven at $70{ }^{\circ} \mathrm{C}$ for 2 hours and at $105{ }^{\circ} \mathrm{C}$ for the next 4 hours. The sample was cooled in the dessicator and the dry weight of sample plus dish taken. The moisture content was calculated as follows:

Percentage (\%) moisture $=\frac{\mathrm{W}_{2}-\mathrm{W}_{3}}{\mathrm{~W}_{2}-\mathrm{W}_{1}} \times \frac{100}{1}$

Where:-

$\mathrm{W}_{1}=$ Initial weight of empty crucible

$\mathrm{W}_{2}=$ Weight of crucible + sample before drying

$\mathrm{W}_{3}=$ Final weight of crucible + sample after drying 
Five grams $(5 \mathrm{~g})$ of finely ground dry sample was weighed into a tarred silica crucible. The sample was charred on a heater inside a fume cupboard, to dry off most of the smoke. The sample was transferred into a pre-heated muffle furnace at $550{ }^{\circ} \mathrm{C}$. It was left at this temperature for 2 hours. After which it was cooled in a dessicator and reweighed.

$\begin{aligned} \text { Percentage (\%) Ash } & =\frac{\text { Weight of ash }}{\text { Weight of original sample }} \times \frac{100}{1} \\ & =\frac{\mathrm{W}_{3}-\mathrm{W}_{1} \times}{\mathrm{W}_{2}-\mathrm{W}_{1}} \frac{100}{1}\end{aligned}$

Where:-

$\mathrm{W}_{1}=$ Weight of empty crucible

$\mathrm{W}_{2}=$ Weight of crucible + sample before drying

$\mathrm{W}_{3}=$ Weight of crucible + ash

\subsubsection{Crude Fibre Content Determination}

Water reflux was boiled for 30 minutes with $200 \mathrm{ml}$ of a solution containing $1.25 \mathrm{~g}$ of $\mathrm{H}_{2} \mathrm{SO}_{4}$ per $100 \mathrm{ml}$ of solution. The solution was filtered through two fold of cheese cloth on a fluted funnel. The residue was washed with boiling water until there was no longer acid. The residue was transferred to a beaker and boiled for 30 minute with $200 \mathrm{ml}$ of a solution containing $1.25 \mathrm{~g}$ of carbonate-free $\mathrm{NaOH}$ per $100 \mathrm{ml}$. The final residue was filtered through a thin but closed pad of washed and ignited asbestos in a Gooch crucible. It was dried in an electric oven and weighed. It was finally incinerated, cooled and weighed.

The loss in weight after incineration $\times 100$ is the percentage of crude fibre.

\subsubsection{Crude Protein Content Determination}

A measured weight $(2 \mathrm{~g})$ of sample was weighed into a $250 \mathrm{ml}$ beaker. After which $75 \mathrm{ml}$ of hot water was added and brought to boil. It was stirred vigorously and added $25 \mathrm{ml}$ of $6 \%$ copper sulphate solution. It was again brought to boil, stirred vigorously and added $25 \mathrm{ml}$ of the $1.25 \%$ sodium hydroxide solution. The mixture was stirred vigorously, removed from the flame and allow to settle. It was filtered through a $15 \mathrm{~cm}$, No. 4 Whatman paper. The precipitate was cleaned from the sides of the beaker with a 'policeman'. The paper was washed free from sulphate with very hot water 6 times. It was allowed to drain well, and then transferred to a Kjeldahl flask containing about $10 \mathrm{~g}$ anhydrous sodium hydroxide and a trace of selenium. Thirty milliliters (30ml) of conc. $\mathrm{H}_{2} \mathrm{SO}_{4}$ was added, nitrogen content determined and hence the protein content of the sample.

Percentage $(\%)$ protein $=\% \mathrm{~N} \times \mathrm{F}$

Where:-

$\mathrm{F}=$ Conversion factor $(6.25)$

Percentage $(\%)$ Nitrogen $=\mathrm{V}_{\mathrm{S}}-\mathrm{V}_{\mathrm{B}} \times$ Nacid $\times 0.028 \times 100$

Where:-

$\mathrm{V}_{\mathrm{S}}=$ Volume of acid required to titrate sample in milliliters

$\mathrm{V}_{\mathrm{B}}=$ Volume of acid required to titrate blank in milliliters

Nacid $=$ normality of acid $(0.1 \mathrm{~N})$

$\mathrm{W}=$ weight of sample in grams

Therefore, Percentage $(\%)$ protein $=\%$ Nitrogen $\times 6.25$.

\subsubsection{Fat Content Determination}

The sample was mixed with a mixture of methanol and chloroform in such proportions to give a single phase miscible with water. Further, extra chloroform was added to give a separation of phases. The solvents were separated by centrifugation. The chloroform layer containing the dissolved fat was removed and fat residue left behind weighed.

Percentage (\%) Fat $=\frac{\text { Weight of fat }}{\text { Weight of sample }} \times \frac{100}{1}$

\subsubsection{Carbohydrate Content Determination}

Carbohydrate content was determined by difference method:

Percentage $(\%)$ Carbohydrate $=100-(\%$ Moisture $+\%$ Ash $+\%$ Crude fibre $+\%$ Crude protein $+\%$ Fat $)$

\subsection{Statistical Analysis}

The data obtained were statistically analyzed using One-Way-ANOVA and the significant difference was established at $(p>0.05)$. The results were expressed as mean $\pm \mathrm{SD}$.

\section{Results}

Considerable high levels of the basic nutrients were present in parts of the six Citrus species Table 1. High levels of carbohydrate were detected in the stems of C. aurantifolia $(67.53 \pm 0.08 \%)$ and C. limon $(50.13 \pm 0.04 \%)$ as well as in the peels of C. grandis $(81.2 \pm 0.06 \%)$, C. reticulata $(75.4 \pm 0.08 \%)$, C. paradisii $(80.6 \pm 0.4 \%)$ and $C$. sinensis $(70.4 \pm 0.05 \%)$. High percentages of fat and crude fibre occurred in the peels of C. aurantifolia $(12.0 \pm 0.4,8.30 \pm 0.4)$, C. limon $(9.01 \pm 0.04,9.37 \pm 0.02)$ and $C$. sinensis $(13.89 \pm 0.02,7.86 \pm 0.02)$ respectively. Fat content was also high in the leaf of $C$. reticulata $(11.10 \pm 0.05 \%)$ and in the stem bark and root of $C$. paradisii $(6.51 \pm 0.06,6.28 \pm 0.4 \%)$ respectively. In addition, high levels of crude fibre were contained in the leaf of $C$. grandis $(7.27 \pm 0.03 \%)$; peel of $C$. reticulata $(9.75 \pm 0.03 \%)$ and leaf of $C$. paradisii $(8.31 \pm 0.02 \%)$. Ash contents were very high in the leaves of $C$. aurantifolia $(14.11 \pm 0.02 \%), C$. limon $(14.15 \pm 0.02 \%)$ and C. paradisii $(13.01 \pm 0.01 \%)$.It was also high in the roots of $C$. 
grandis $(12.72 \pm 0.04 \%)$ as well as in the stem bark of C. reticulata $(15.18 \pm 0.02 \%)$ and C. sinensis (17.01 $\pm 0.01 \%)$. Appreciable high values of ash were also detected in the leaves of $C$. grandis (10.18 $\pm 0.02 \%)$ and root of $C$. paradisii $(10.14 \pm 0.01 \%)$ Table 1 .

\section{Discussion}

High carbohydrate values were ranged from 70 to 81 percent in the peels of C. grandis, C. reticulata, C. paradisii and $C$. sinensis. Carbohydrate and fat provide animal body with energy. Energy (mainly from carbohydrates) and protein are the primary macro nutrients to take into account, for beef cattle nutrition [9]. High percentage of fat was also present in the range of 12 to 13 in the peels of $C$. aurantifolia and C. sinensis. Fat is a solvent for fat-soluble vitamins and hormones. Reasonable levels of crude fibre were found in the leaves (except $C$. sinensis) and peels (with the exception of $C$. grandis), of all the Citrus species tested. Fibre promotes digestion, cleanses the digestive tract, prevents absorption of excess cholesterol [18] and aids in bowel movement by adding mass to the intestinal content [19]. Digestion of animal feed is therefore, determined by the crude fibre content [20]. Ash contents were very high in the leaves of $C$. aurantifolia, $C$. grandis, $C$. limon and $C$. paradisii, ranging from 10 to $14 \%$. The ash values were higher than the ones found in leaves $10.85 \%$ of Ipomoea batatas (L.) Lam. (sweet potatoes) [15]. Ash of a food material contains mineral matter. Mineral salts are needed for regulation of body metabolism. Crude protein was found in high levels ranging from 15 to 18 percent in the leaves of all the Citrus species investigated. The percentage crude protein values were higher than the levels present in the Zea mays L. (corn) grain 9.5-11.2, Sorghum bicolor (L.) Moench (milo, sorghum) grain 10.3-11.0 and Glycine max L. Merr. (soybean) leaf 11.0-13.1 [21]. Moreover, the values in the peels of C. aurantifolia, C. limon, C. reticulata and C. sinensis that ranged from $6.4-10.7 \%$ were higher than the levels found in leaf $6.2-7.8 \%$, husk $3.0-4.0 \%$, cob $2.1-3.8 \%$ and stalk $3.4-4.9 \%$ of corn; stem $3.6-4.5 \%$ and pod $4.5-9.0 \%$ of soybean, and stalk $3.3-3.9 \%$ of milo.

Beef is the major meat consumed in Nigeria and the meat quality is primarily dependent on the feed quality. Pastoralism, agro-pastoralism and ranching systems are three major beef cattle production systems in Nigeria [22] with the pastoralism and agro-pastoralism being the principal systems. Ranching system involves semi-intensive and intensive feeding systems, where the animals' nutritional needs are supplemented with diets as additional feed. The nutrient requirements of animals differ because of a number of factors, including age, body condition, body size, pregnancy and lactation. These factors as well as forage quantity and forage quality are considered in determining the supplementation need of animals. For sustainable farming, easy availability of local feeds and supplements is essential. This can be achieved by sourcing for local plant species of high nutritional values. According to United States Department of Agriculture [23] the development of animal feeds entails mixing various readily obtainable and low cost feed materials into a ration that will provide nutrient requirements for animals. In addition, having the information on the chemical composition of the various available feed ingredients is a critical factor. The dietary crude protein used in diets formulated by some consultants ranged from 12.5 to $14.4 \%$ but most consultants use at least $13 \%$ crude protein [24] whilst at least 15 percent crude protein is required for creep feeds or forages for nursing calves [25]. This indicated that leaves of these Citrus species could be used as protein supplement to enrich animal feed, because protein is needed by animal body in large amounts. Sweet potato vine silage contained $136.1 \mathrm{~g} \mathrm{~kg}^{-1} \mathrm{DM}$ crude protein and had been suggested for supplementing tropical cattle [26]. Soybean contained 44\% [27] and 49.0-52.0\% crude protein value[21]. Soybean meal is the most common protein source for all compound feeds for pigs, poultry and dairy cattle globally; however, it is seldom too costly [27].The finding therefore, suggested an inclusion of Citrus plants leaves and peels in plant food protein, indicating that they can potentially be used as easily available protein sources for livestock production. Providing adequate protein in beef cattle diets is essential for animal health and productivity as well as ranch profitability [25]. Besides, young, growing cattle, in particular, need relatively high levels of crude protein in their diets to support muscle growth.

Moreover, when forage crude protein levels fall below 6 to $8 \%$, the protein supplementation is highly needed[28]. This is as a result of low quality of the forage. Citrus parts could therefore, be used to solve the problem of shortage of good quality feeds needed to sustain livestock growth especially during the dry season, which in turn, will support livestock productivity. Insufficient good quality animal feeds result to serious effects on cattle such as lessened pregnancy rates; loss of body condition of the cow, and reduce milk production, hence lowers weaning weights [29]. In addition, other alternative feeds are mostly in short supply and costly. Cost of feeding is the most expensive part of livestock production [30]. Cost is also the primary factor for supplementing additional protein in finishing diets [24]. These indicated that the leaves and peels of these Citrus species could potentially be used as inexpensive and readily accessible feedstuffs for livestock production. Moreover, high level of crude protein in these Citrus species leaves indicated that they can serve as cheap sources of protein.

\section{Conclusion}

The study revealed that the leaves and peels of these Citrus species contained high nutritive values. They are also environmentally friendly, readily available and relatively cheap. Hence, suggesting their potential use in development of animal feed for more sustainable feeding system. In addition, protein is the most expensive and critical nutrient needed by animal body in large amounts. Therefore, incorporation of these parts as protein supplement in animal feeds to enhance animal nutrition is recommended. Further research however, is necessary in order to assess the effect of the diet on animal nutrient digestibility and growth performance. 
Table-1. Proximate composition of leaf, peel, stem, stem bark and root of six Citrus species.

\begin{tabular}{|c|c|c|c|c|c|c|}
\hline \multirow{2}{*}{ Citrus Species } & \multirow{2}{*}{ Nutrients } & \multicolumn{5}{|c|}{ Plant Parts (\%) } \\
\hline & & Leaf & Peel & Stem & Stem Bark & Root \\
\hline \multirow{6}{*}{ Citrus aurantifolia } & Crude protein & $16.69 \pm 0.07$ & $6.38 \pm 0.4$ & $6.27 \pm 0.04$ & $7.81 \pm 0.01$ & $9.38 \pm 0.02$ \\
\hline & Carbohydrate & $41.76 \pm 0.04$ & $53.89 \pm 0.4$ & $67.53 \pm 0.08$ & $56.86 \pm 0.12$ & $55.17 \pm 0.01$ \\
\hline & Fat & $9.39 \pm 0.01$ & $12.0 \pm 0.4$ & $2.88 \pm 0.03$ & $6.17 \pm 0.03$ & $5.71 \pm 0.01$ \\
\hline & Ash & $14.11 \pm 0.02$ & $5.82 \pm 0.04$ & $6.47 \pm 0.01$ & $11.27 \pm 0.03$ & $13.61 \pm 0.01$ \\
\hline & Crude fibre & $6.77 \pm 0.02$ & $8.30 \pm 0.4$ & $5.74 \pm 0.03$ & $5.68 \pm 0.03$ & $5.23 \pm 0.4$ \\
\hline & Moisture & $12.86 \pm 0.04$ & $11.29 \pm 0.06$ & $11.13 \pm 0.01$ & $12.07 \pm 0.02$ & $10.87 \pm 0.02$ \\
\hline \multirow{6}{*}{ C. grandis } & Crude protein & $16.27 \pm 0.04$ & $1.0 \pm 0.02$ & $6.52 \pm 0.01$ & $6.32 \pm 0.4$ & $8.77 \pm 0.3$ \\
\hline & Carbohydrate & $49.72 \pm 0.1$ & $81.2 \pm 0.06$ & $66.63 \pm 0.10$ & $62.14 \pm 0.05$ & $56.85 \pm 0.4$ \\
\hline & Fat & $5.24+0.4$ & $0.7 \pm 0.01$ & $2.77 \pm 0.03$ & $5.85 \pm 0.4$ & $5.25 \pm 1.01$ \\
\hline & Ash & $10.18 \pm 0.02$ & $2.1 \pm 0.05$ & $7.27 \pm 0.2$ & $8.18 \pm 0.02$ & $12.72 \pm 0.04$ \\
\hline & Crude fibre & $7.27 \pm 0.03$ & $4.5 \pm 0.4$ & $5.28 \pm 0.01$ & $4.81 \pm 0.01$ & $5.85 \pm 0.4$ \\
\hline & Moisture & $11.33 \pm 0.03$ & $19.2 \pm 0.03$ & $11.45 \pm 0.05$ & $12.69 \pm 0.01$ & $10.57 \pm 0.01$ \\
\hline \multirow{6}{*}{ C. limon } & Crude protein & $15.51 \pm 0.04$ & $7.30 \pm 0.01$ & $4.80 \pm 0.01$ & $7.02 \pm 0.03$ & $10.25 \pm 0.01$ \\
\hline & Carbohydrate & $39.03 \pm 0.01$ & $41.35 \pm 0.03$ & $50.13 \pm 0.04$ & $47.05 \pm 0.1$ & $42.03 \pm 0.02$ \\
\hline & Fat & $7.23 \pm 0.03$ & $9.01 \pm 0.04$ & $1.13 \pm 0.03$ & $5.25 \pm 1.01$ & $4.35 \pm 0.01$ \\
\hline & Ash & $14.15 \pm 0.02$ & $5.91 \pm 0.01$ & $6.01 \pm 0.01$ & $12.08 \pm 0.04$ & $11.05 \pm 0.05$ \\
\hline & Crude fibre & $6.80 \pm 0.01$ & $9.37 \pm 0.02$ & $5.86 \pm 0.01$ & $6.30 \pm 0.01$ & $7.52 \pm 0.02$ \\
\hline & Moisture & $12.31 \pm 0.04$ & $15.31 \pm 0.05$ & $13.01 \pm 0.05$ & $14.07 \pm 0.02$ & $12.70 \pm 04$ \\
\hline \multirow{6}{*}{ C. reticulata } & Crude protein & $15.86 \pm 0.04$ & $8.95 \pm 0.03$ & $7.29 \pm 0.01$ & $6.21 \pm 0.02$ & $8.79 \pm 0.04$ \\
\hline & Carbohydrate & $42.17 \pm 0.06$ & $75.4 \pm 0.08$ & $69.31 \pm 0.06$ & $56.84 \pm 0.05$ & $56.14 \pm 0.07$ \\
\hline & Fat & $11.10 \pm 0.05$ & $9.02 \pm 0.4$ & $3.07 \pm 0.01$ & $6.29 \pm 0.01$ & $6.04 \pm 0.02$ \\
\hline & Ash & $11.53 \pm 0.08$ & $13.04 \pm 0.04$ & $4.28 \pm 0.02$ & $15.18 \pm 0.02$ & $13.34 \pm 0.06$ \\
\hline & Crude fibre & $6.81 \pm 0.3$ & $9.75 \pm 0.03$ & $4.91 \pm 0.01$ & $4.74 \pm 0.02$ & $5.30 \pm 04$ \\
\hline & Moisture & $12.54 \pm 0.02$ & $15.32 \pm 0.02$ & $11.16 \pm 0.04$ & $10.76 \pm 0.03$ & $10.41 \pm 0.02$ \\
\hline \multirow{6}{*}{ C. paradisii } & Crude protein & $18.13 \pm 0.05$ & $0.4 \pm 0.01$ & $6.43 \pm 0.4$ & $6.01 \pm 0.03$ & $8.41 \pm 0.03$ \\
\hline & Carbohydrate & $40.65 \pm 0.04$ & $80 . \overline{6}+0.4$ & $60.48 \pm 0.07$ & $58.31 \pm 0.05$ & $51.02 \pm 0.01$ \\
\hline & Fat & $5.03 \pm 0.4$ & $0.3 \pm 0.01$ & $2.83 \pm 0.03$ & $6.51 \pm 0.06$ & $6.28 \pm 0.4$ \\
\hline & Ash & $13.01 \pm 0.01$ & $1.30 \pm 0.02$ & $6.32 \pm 0.04$ & $7.82 \pm 0.04$ & $10.14 \pm 0.01$ \\
\hline & Crude fibre & $8.31 \pm 0.02$ & $2.3 \pm 0.05$ & $5.01 \pm 0.01$ & $4.98 \pm 0.02$ & $4.71 \pm 0.01$ \\
\hline & Moisture & $13.31 \pm 0.02$ & $17.4 \pm 0.03$ & $9.33 \pm 0.02$ & $14.05 \pm 0.05$ & $12.31 \pm 0.04$ \\
\hline \multirow{6}{*}{ C. sinensis } & Crude protein & $16.03 \pm 0.02$ & $10.74 \pm 0.01$ & $8.09 \pm 0.02$ & $6.35 \pm 0.01$ & $9.31 \pm 0.04$ \\
\hline & Carbohydrate & $39.97 \pm 0.07$ & $70.4 \pm 0.05$ & $61.48 \pm 0.02$ & $53.71 \pm 0.02$ & $41.08 \pm 0.02$ \\
\hline & Fat & $11.53 \pm 0.08$ & $13.89 \pm 0.02$ & $5.01 \pm 0.03$ & $7.31 \pm 0.03$ & $8.01 \pm 0.02$ \\
\hline & Ash & $10.61 \pm 0.02$ & $11.90 \pm 0.07$ & $5.31 \pm 0.05$ & $17.01 \pm 0.01$ & $11.57 \pm 0.03$ \\
\hline & Crude fibre & $4.93 \pm 0.02$ & $7.86 \pm 0.02$ & $5.05 \pm 0.01$ & $5.31 \pm 0.07$ & $4.27 \pm 0.01$ \\
\hline & Moisture & $14.61 \pm 0.02$ & $15.71 \pm 0.03$ & $12.09 \pm 0.01$ & $10.93 \pm 0.03$ & $9.91 \pm 0.4$ \\
\hline
\end{tabular}

Note: Results are in Mean \pm SE of triplicate determinations, $(p>0.05)$.

\section{References}

[1] B. P. Pandey, A text book of botany angiosperms, 2nd ed. New Delhi: Chand and Company Limited, 1981.

[2] H. I. Manner, R. S. Buker, V. E. Smith, and C. R. Elevitch, Citrus species (citrus), In: C. R. Elevitch, (Ed.). Species profiles for pacific Island agroforestry. Hawai' i: Permanent Agriculture Resources, 2006.

[3] J. F. Morton, Fruits of warm climates. Florida: Flair Books, 1987.

O. P. Sharma, Plant taxonomy. New Delhi: Tata McGraw-Hill Publishing Company Limited, 1993.

G. Singh, Plant systematics, 3rd ed. New Delhi, Oxford IDH: Publishing Co Pvt. Ltd, 2004.

D. Abeysinghe, X. Li, C. Sun, W. Zhang, C. Zhou, and K. Chen, "Bioactive compounds and antioxidant capacities in different edible tissues of citrus fruit of four species," Food Chemistry, vol. 104, pp. 1338-1344, 2007. Available at: https://doi.org/10.1016/j.foodchem.2007.01.047.

[7] S. Chanthaphon, S. Chanthachum, and T. Hongpattarakere, "Antimicrobial activities of essential oils and crude extracts from Tropical Citrus species against food-related microorganisms," Songklanakarin Journal of Science and Technology, vol. 30, p. 125-131, 2008.

[8] M. Razzaghi-Abyaneh, M. Shams-Ghahfarokhi, M.-B. Rezaee, K. Jaimand, S. Alinezhad, R. Saberi, and T. Yoshinari, "Chemical composition and antiaflatoxigenic activity of Carum carvi L., Thymus vulgaris and Citrus aurantifolia essential oils," Food Control, vol. 20, pp. 1018-1024, 2009. Available at: https://doi.org/10.1016/j.foodcont.2008.12.007.

[9] M. Vickers, Feeding growing and finishing cattle for better returns. Warwickshire: Agriculture and Horticulture Development Board, Beef Better Returns Programme Manual 7, 2016.

[10] G. M. Wardlaw, Contemporary nutrition: Issues and insights, 3rd ed. New York: MCB/McGraw-Hill, A Division of the McGraw-Hill Companies Incorporated, 1997.

[11] H. P. S. Makkar, Animal nutrition: Beyond the boundaries of feed and feeding. Rome: Food and Agriculture Organization of the United Nations, Animal Production and Health Division, Broadening Horizons $\mathrm{N}^{\circ} 31,2016$.

[12] G. M. Wardlaw, Contemporary nutrition: Issues and Insights, 5th ed. New York: McGraw-Hill Companies Incorporated, 2005.

[13] K. Tibi and A. Aphunu, "Analysis of the cattle market in Delta State-the supply determinants," African Journal of General Agriculture, vol. 6, pp. 199-203, 2010.

[14] H. Kubkomana, "Indigenous breeds of cattle, their productivity, economic and cultural values in sub-saharan Africa: A review," International Journal of Research studies in Agricultural Sciences, vol. 3, pp. 27-43, 2017. Available at: https://doi.org/10.20431/24546224.0301004.

[15] F. Abonyi, E. Iyi, and N. Machebe, "Effects of feeding sweet potato (Ipomoea batatas) leaves on growth performance and nutrient digestibility of rabbits," African Journal of Biotechnology, vol. 11, pp. 3709-3712, 2012.

[16] P. Bamaiyi, "Factors militating against animal production in Nigeria," International Journal of Livestock Research, vol. 3, pp. 54-66, 2013.

[17] G. I. Onwuka, Food analysis and instrumentation: Theory and practice. Lagos: Naphthali Prints, A Division of HG Support Nigeria Limited, 2005.

[18] C. A. Ezeabara, C. U. Okeke, and J. E. Amadi, "Phytochemical, proximate, mineral and vitamin investigations of cormels of five varieties of Colocasia esculenta (L.) Schott found in Anambra State, Southeastern Nigeria," American Journal of Life Science Researches, vol. 3, p. 273-281, 2015 .

[19] C. A. Ezeabara and E. U. Mbah, "Comparative phytochemical and proximate investigations of leaf, root and stem of Mimosa invisa Mart. and M. pudica L," Journal of Pharma Science, vol. 1, p. 56 - 63, 2016. 
[20] M. Staniak, "Changes in yield and nutritive value of red clover (Trifolium pratense L.) and Festulolium (Festulolium braunii (K. Richt) A. Camus) under drought stress," Agricultural and Food Science, vol. 28, pp. 27-34, 2019. Available at: https://doi.org/10.23986/afsci.73282.

[21] R. J. Rasby, M. E. Drewnoski, and A. Stalker, Grazing crop residues with beef cattle. Lincoln: University of Nebraska-Lincoln, University of Nebraska-Lincoln Extension EC 278, 2014.

[22] C. Nwigwe, V. Okoruwa, K. Adenegan, and A. Olajide, "Competitiveness of beef cattle production systems in Nigeria: A policy analysis approach," Journal of Agriculture and Sustainability, vol. 9, pp. 175-197, 2016.

[23] United States Department of Agriculture, Animal diets and feed management. Washinton DC: Natural Resources Conservation Service, Nutrient Management Technical Note No. 8, 2012.

[24] A. Di Costanzo, Protein requirements of feedlot cattle. Minnesota: University of Minnesota, Minnesota Cattle Feeders Report B - 432, 1996.

[25] J. Parish, Protein requirements of beef cattle. Mississippi: Mississippi State University, Cattle Business in Mississippi - Beef Production Strategies, 2009.

[26] A. I. M. Ali, S. E. Wassie, D. Korir, L. Merbold, J. P. Goopy, K. Butterbach-Bahl, U. Dickhoefer, and E. Schlecht, "Supplementing tropical cattle for improved nutrient utilization and reduced enteric methane emissions," Animals, vol. 9, p. 18, 2019. Available at: https://doi:10.3390/ani9050210.

[27] I. Mavromichalis, Six alternative protein sources to soybean meal, In J. Roembke, (Ed.). Feed Strategy. Rockford: Watt Global Media, 2018.

[28] J. Parish, Feed intake in beef cattle - the quest for efficiency. Mississippi: Mississippi State University, Cattle Business in Mississippi Beef Production Strategies, 2005.

[29] L. Stewart, T. Dyer, R. Silcox, J. Rossi, and R. Stewart, Drought management strategies for beef cattle. University of Georgia: UGA Cooperative Extension Bulletin 1323, 2017.

[30] U. K. Saha, S. S. Sonon, D. Hancock, N. S. Hill, L. Stewart, G. L. Heusner, and D. E. Kissel, Common terms used in animal feeding and nutrition. University of Georgia: UGA Cooperative Extension Bulletin 1367, 2017. 